\title{
Dalibor Davidović
}

Akademija za glasbo, Univerza v Zagrebu

Music Academy, University of Zagreb

\section{Branches}

\section{Veje}

Prejeto: 17. januar 2015

Sprejeto: 31. marec 2015

Ključne besede: anarhija, programska glasba, improvizacija, poezija, znanje (v glasbi)

\section{IZVLEČEK}

Članek, ki za svojo osnovo vzame pogovor med Johnom Cageom in Geoffreyjem Barnardom - izdanim kot Pogovor brez Feldmana (Conversation without Feldman) -, raziskuje Cageevo idejo anarhije.
Received: 17th January 2015

Accepted: 31st March 2015

Keywords: Anarchy, Program music, Improvisation, Poetry, Knowledge (in music)

\section{ABSTRACT}

Taking the conversation between John Cage and Geoffrey Barnard - published as Conversation without Feldman - as a starting point, the following article explores Cage's notion of anarchy.

"Inwiefern ist die ratio eine Zwiesel?"1

Conversation without Feldman is a transcript of a conversation between two musicians. The older one, John Cage, was at that time already an artist with an international reputation, primarily as a composer but also as a writer and poet, and occasionally as a performer of his own pieces. Behind him were already some retrospectives, such as the famous 25-year Retrospective Concert that took place in 1958. Behind him was the famous appearance at the International Summer Course for New Music in Darmstadt in 1958, a shocking experience for many of his European colleagues. Behind him were the extravagant multimedia productions which took place during the late sixties and involved the participation of hundreds of performers and the use of the newest technologies. Behind him were already four collections of writings, not just lectures and articles dedicated to what he called experimental music, but also poetic cycles and the Diary series. Behind 
him were already some visual works of art, the first of them having been realized in the late sixties. From 1978 (when the Conversation without Feldman took place) on, these works' part in Cage's output and their importance for the other fields of his work would significantly grow. ${ }^{2}$ Finally, behind him were the covers of the influential magazines producing and spreading the image of a "not just well-known, but notorious" 3 public person.

In contrast to that, the younger dialogue partner, Geoffrey Barnard, was at that time just at the beginning of his career. Behind him was the experience of participation in the group AZ Music founded in Sydney in the early seventies by the composer David Ahern after his return from London. Having been involved with the Scratch Orchestra, Ahern took it as a model and established in Sydney a free weekly class in experimental and improvised music, and this gradually developed into the ensemble. Just like its model, AZ Music was soon confronted with inner doubts concerning its orientation and subsequently split into different groups and side-projects, ${ }^{4}$ giving its members the bitter feeling that life had brought something that they initially didn't want.

In this situation of crisis, Barnard, plagued by the question which way his musical career should take after this discouraging experience, approached Cage in order to ask him for some advice. Why Cage? From the very beginning of the conversation Barnard let his dialogue partner know that the conversation should be taken as a kind of return to the origin. For it was Cage who, in the foreword to his collection of writings titled $A$ Year from Monday, expressed a call for a certain way of getting musical things done:

\section{The reason I am less and less interested in music is not only that I find environmental sounds and noises more useful aesthetically than the sounds produced by the world's musical cultures, but that, when you get right down to it, a composer is simply someone who tells other people what to do. I find this an unattractive way of getting things done. I'd like our activities to be more social and anarchically so. ${ }^{5}$}

Among the responses to Cage's proposal to make musical activities more social and anarchically so was also AZ Music. Turned "against the tyranny of the self-contained music-object, not only that which had emerged out of the tradition of tonal functional harmony, but also that which embodied the authoritarianism of serialism and subsequent developments in European contemporary composition," ${ }^{6}$ the group primarily used verbal instructions, graphic scores or catalogues of sound situations as a starting point for improvisation. The performances demanded of the members of the group that they listen to the other members while making music, instead of being dominated by the prefabricated structures and fixed relations, thus "affirming a stance that is essentially anarchistic." 7

On the genesis of these works cf. Joan Retallack, ed., Musicage: Cage Muses on Words / Art/Music (Hanover \& London: Wesleyan University Press, 1996), 95 et seqq.

3 James Pritchett, The Music of John Cage (Cambridge: Cambridge University Press, 1993), 140.

4 Cf. Geoffrey Barnard, "AZ it was," New Music Articles 8, no. 7 (1989); accessed 10 February, 2015, http://www.rainerlinz.net/ NMA/repr/Barnard.html.

5 John Cage, A Year from Monday: New Lectures and Writings (Middletown: Wesleyan University Press, 1967), ix et seq

6 Barnard, "AZ it was."

7 Barnard, "AZ it was." 
Not just the other individual, but also Cage himself responded with his activities to his own call to arms cited above. Although already in Silence, his first collection of writings, he had characterized his own "views" as "consistently antischolastic and anarchic," ${ }^{\circ}$ his references to anarchy would not take the decided tone until the late sixties. Such references occurred frequently in his Diary, including not just quotations from other texts related to anarchy - almost always of those by Thoreau - but also the very definition of anarchy:

Society, not being a / process a king sets in motion, becomes an / impersonal place understood and made / useful so that no matter what each / individual does his actions enliven the / total picture. Anarchy (no laws or / conventions) in a place that works. / Society's individualized. ${ }^{9}$

Taking such references as markers for their own research, some Cage scholars found in his music certain traits of anarchy. Thus James Pritchett, the author of the standard monograph on Cage as a composer, spoke of anarchy while referring to the group of his works from the sixties, which could be named "circuses." ${ }^{10}$ The performances of the respective pieces, like Musicircus or HPSCHD, included not just a simultaneous playing of many different ensembles (orchestras, groups specialized in contemporary music, jazz and brass bands, etc.) in the same concert hall, but also visual attractions like slide projections and even balloons:

In sum, a musical anarchy was produced, wherein the performers and listeners were no longer told what to do, and Cage retreated to such a distance that his role as organizer and designer, while crucial, was practically invisible. The circus events represented yet another variation on the music-as-process idea, this time turning music into an activity for society at large. ${ }^{11}$

Rob Haskins undertook comprehensive research of the anarchist "principles" or "ideas," 12 finding them subsequently realized in Cage's works, even in those ones composed during the last years of the composer's life. Known as Number Pieces, these works seem to be so far from the extravagant circuses mentioned above:

[T] The transparency of the Number Pieces echoes the important anarchistic idea advocating no ownership of property and a modest lifestyle for humanity. [...] The relationship of players in the ensemble pieces suggests that most of these works also exemplify anarchistic practice in that they put no one player or group of players in a hierarchical relationship over another. [...] In this sense, Cage's music is didactic; it allows performers to be shaped by the network of ideas underlying his aesthetics, including those of classic anarchism. ${ }^{13}$ 
In the conversation between Cage and Barnard some other Cage pieces were mentioned as examples of music intended to be more social and anarchically so. ${ }^{14}$ Both of his then recent pieces, Branches and Inlets (together with the earlier piece with the title Child of Tree), are indeed exceptional cases in his oeuvre, not so much because of the rather extensive part of indeterminate details, but because of the outstanding role given to improvisation, a procedure which for Cage was always under suspicion for bringing the performer's arbitrariness into composition, making it thus a potential source of musical clichés. All of these pieces consist just of verbal instructions for the performance. While the composition Child of Tree is actually for solo percussion, the piece Branches can be performed, optionally, by just one or by many players. At the same time both pieces are connected in a certain way, since every performance of Branches includes a preparation of the material of the earlier piece. Only the dimension of duration ( 8 minutes) and, partially, the dimension of sound sources of the piece Child of Tree are determined, because for its performance a pod of a poinciana tree and a cactus, live or dry, should be used - namely, a cactus "of a genus having a solid body and spines which are relatively free of other spines, so that when one spine is plucked (by means of a needle or toothpicks etc.), a single pitched sound issues." ${ }^{15}$ The performer can choose from another eight "instruments" 16 freely, but should avoid those made of animal or metal materials as well as the "conventionally pitched instruments"17 - conventionally pitched in the sense of producing sounds with fixed pitch. Other dimensions of the piece - the number of sections within the total duration of the piece, the number of instruments within every section and their actual arrangement - should be determined by I Ching using the tables for the distribution of numbers given in the instructions for the performance. After determination of these dimensions, the soloist "improvises, clarifying the time structure by means of the instruments," and "this improvisation" is actually "the performance." 18

Branches are not just the development of the Child of Tree, but this piece includes the whole earlier piece in a certain way. In contrast to the fixed duration of the Child of Tree, the duration of Branches can vary from performance to performance according to the number of "variations"19 - that is realizations of the Child of Tree, each of them lasting eight minutes. These variations, separated through silences whose duration should be determined using I Ching, actually constitute the performance of the later piece. The variations can follow successively, but can also be played simultaneously, if many players perform the piece, in which every one can begin optionally with silence.

Neither in Inlets did the composer fix the duration of the performance, though this is not the case with the sound sources of this piece: twelve water-filled conch shells of different sizes should be "tipped this way or that" by three players, thus producing

14 Cf. John Cage and Geoffrey Barnard, Conversation without Feldman (Darlinghurst: Black Ram Books, 1980), 14.

15 John Cage, Child of Tree: Percussion Solo (New York: Henmar Press \& Edition Peters, 1975), 2.

16 Cage, Child of Tree ..., 1 (quotation marks in the original).

17 Cage, Child of Tree ..., 3.

18 Cage, Child of Tree ..., 7.

19 John Cage, Branches: Percussion Solo, Duet, Trio or Orchestra (of any Number of Players) (New York: Henmar Press \& Edition Peters, 1976), 1. 
"gurgles." ${ }^{20}$ Every one of the players is free to choose the order of the use of his four conch shells, dedicating more time to the next one. Halfway through the agreed time of the performance three players should reduce their activities in order to let the tape recording of the sound of pine cones burning fade in. In the second half of the performance, after the comeback of the gurgles, the fourth player should use a conch shell "as trumpet"21 for as long as he can hold a single tone.

Encouraged by Cage's development toward music in which the improvisation equals the performance, Barnard recognized in the pieces mentioned above a "situation where people are free to do what they do without interfering with the others or telling the others what to do,"22 a situation which resembled the practice of younger groups for improvised music - among them the group of which he was a member. Cage met him halfway, claiming that the intention of his pieces is "to try to persuade people." ${ }^{23}$ Are Cage's pieces therefore a kind of appeal to our mind? Connecting them with the "nature imagery" ${ }^{4}$ in Cage's musical poetics, Pritchett discusses them under the notion of "program music." 25 But what do they narrate, communicate, evoke? How do they do this? The narrative line is perhaps easiest to recognize in Inlets, since its sound materials seem to have almost the function of different themes, all the more so as their order of appearance was determined by the composer. The first half of the piece is dominated by gurgles, in the middle of the piece there appears the sound of pine cones burning, and after this the gurgles return. Finally the long sustained sound of the conch shell as trumpet rises, being recognizable as a rudimentary melodic line in the foreground. What does this sequence of sound materials mean? Is it a wakeup call in order to save the initial idyllic scene from catastrophe, represented by the sound of fire? Does the long sustained sound of conch shell used as a trumpet cue some apocalyptic events? On the other hand, do the plant materials used as instruments make these pieces ecological, in contrast to music written for conventional instruments, with those instruments that can produce tones with fixed pitch being at the same time violent toward nature? Does Child of Tree, a piece whose duration is determined by the composer, refer to something compact like a tree, in contrast to Branches, a piece that resembles a cycle of variations being bifurcated like the branches of the tree? Do the sounds of plant materials - including the living cactus - evoke a natural soundscape? And the sound of a pod of the poinciana tree, reserved for the final section of the piece, ${ }^{26}$ does it not resemble the rustle of the treetops? Should the piece remind us that we are actually children of a tree?

Finally, Cage remained committed to anarchy also in his later works, perhaps most explicitly in his cycle of twelve poems titled simply Anarchy. The poems have different lengths, according to the different lengths of their vertical "strings": some of them are

20 John Cage, Inlets: For three Players, with Conch Player (using Circular Breathing) and the Sound of a Fire (New York: Henmar Press \& Edition Peters, 1977), 1.

21 Cage, Inlets ..., 1.

22 Cage and Barnard, Conversation without Feldman, 14.

23 Ibid., 14.

24 Pritchett, The Music of John Cage, 194 et seq.

25 Ibid., 189 et seq.

26 Cf. Cage, Child of Tree ..., 3 ("Arrange the instruments so that it is easily (known) which is number 1, which is number 2 etc. Pod rattles is number 10.") and 4 ("Reserving the 10 th instr. for the last part..."). 
thus composed of just a dozen lines, in contrast to the hundreds of lines in the case of the longer ones. The textual sources of the whole cycle are thirty quotations of different lengths taken from 19th and 20th-century texts (essays, poems, pamphlets, diaries, memoirs, biographies, graffiti, and Cage's previous writings) that deal in one way or another with the subject of anarchy. ${ }^{27}$ The quotations were used both as vertical strings of the poems and as the material for the horizontal lines. In some poems just the name of the quotation's author was taken as a string, ${ }^{28}$ while in other ones the whole quotation was used. ${ }^{29}$ The I Ching determined which quotation was used as the string of the respective poem and it also made the decision on the actual number of quotations used as the sources of its horizontal lines. ${ }^{30}$

Cage was concerned with quotations not just as the sources of the textual material, but also as statements on the subject of anarchy, as their occurrence in the foreword to the cycle testifies. And the quotations themselves leave not much space for doubt as to what they stand for:

Periods of very slow changes are succeeded by periods of violent changes. Revolutions are as necessary for evolution as the slow changes which prepare them and succeed them. ${ }^{31}$

I heartily accept the motto, "That government is best which governs least"; and I should like to see it acted up to more rapidly and systematically. Carried out, it finally amounts to this, which also I believe - "That government is best which governs not at all"; and when men are prepared for it, that will be the kind of government which they will have. ${ }^{32}$

Anarchism, then, really stands for the liberation of the human mind from the domination of religion; the liberation of the human body from the domination of property;

27 All the quotations are taken from Cage's previous collections of writings $A$ Year from Monday (quotations no. 2, 4, 6, 8, 10, 12, 14 and 16) and $M$ (no. 18, 21 and 25). Represented with more than one quotation are also Emma Goldman (no. 17, 20, 22 and 30), Henry David Thoreau (no. 13 and 29), Mikhail Bakunin (no. 5 and 28) and Buckminster Fuller (no. 24 and 26). Represented with just one quotation are Peter Kropotkin (no. 1), Errico Malatesta (no. 2), Albert Einstein (no. 7), Leo Tolstoy (no. 11), Walt Whitman (no. 15), Hippolyte Havel (no. 19), Paul Goodman (no. 23) and Norman O. Brown (no. 27). No. 9 is a quotation of the graffiti which Andrew Culver, the assistant of Cage, noticed in 1987 in the New York City Subway. Cf. John Cage, "Anarchy," in John Cage at Seventy-Five, ed. Richard Fleming and William Duckworth (Lewisburg \& London \& Toronto: Bucknell University Press \& Associated University Presses, 1989), 123 et seqq.

28 Such are poems no. 1 (where the name "peter kropotkin" appears as a string), no. 8 ("hippolyte havel"), no. 9 ("leo tolstoy"), no. 17 ("henry david thoreau"), no. 18 ("michael bakunin") and no. 20 ("buckminster fuller"). Poem no. 12 doesn't have Cage's name as a string, but the title of his collection of writings ("a year from monday"), where the quotation is taken from.

29 This is the case in poems no. 2 (where quotation no. 25 appears as a string), no. 3 (quotation no. 10), no. 4 (quotation no. 9), no. 5 (quotation no. 11), no. 6 (quotation no. 16), no. 7 (quotation no. 14), no. 10 (quotation no. 24), no. 11 (quotation no. 2), no. 13 (quotation no. 21), no. 14 (quotation no. 15, shorten for a line), no. 15 (quotation no. 7), no. 16 (quotation no. 8) and no. 19 (quotation no. 23).

30 It is difficult to reconstruct solely according to the text of the cycle which quotations were used as sources of the horizontal lines in every poem, but in some of them this is possible. For example, when some letters of the source are absent in the string, the horizontal lines must have been derived from the limited number of quotations or from those quotations which don't contain the respective letters. Such are poems no. 3 (where the lines are derived just from quotation no. 18) and no. 6 (where the lines are derived just from quotation no. 16, which appears at the same time as the string of the poem).

31 Quotation no. 1, taken from Peter Kropotkin's Revolutionary Studies; cf. Cage, "Anarchy," 123.

32 Quotation no. 13, taken from Henry David Thoreau's Essay on the Duty of Civil Disobedience; cf. Cage, "Anarchy," 124 et seq. 
liberation from the shackles and restraint of government. Anarchism stands for a social order based on the free grouping of individuals for the purpose of producing real social wealth; an order that will guarantee to every human being free access to the earth and full enjoyment of the necessities of life, according to individual desires, tastes, and inclinations. ${ }^{33}$

Returning to Cage, Barnard returned to the origin. He came to Cage as if he wanted to have it confirmed that he was on the right path. Cage seemed to meet him halfway, to agree with his opinions. Cage thus announced that Empty Words, his new collection of writings, would take an explicit political stance in the face of current events. He seemed to be interested in new anarchist ways of life and asked Barnard whether these ways included changes in nutrition. Music was just one of the subjects of their conversation. They acclaimed its recent changes. Moreover, music should be changed in order to be able to change the society in the right way. And yet, though agreeing with Barnard on many subjects, including the subject of music changes, Cage seemed to be distant at the same time. Barnard thus mentioned some of the newest examples of the political direction that certain composers were taking in their music. He was "encouraged" ${ }^{44}$ by some of them, but was not sure whether they should be followed. In contrast to that, he found the direction that Cornelius Cardew took in his later pieces to be a wrong one. Cardew's later pieces, mostly variations on revolutionary songs or on the songs of the labour movement, were discussed on two occasions during the conversation. It was as if Barnard's remarkable devotion to this subject and the intensity of his discussion were symptoms of a certain wound that just wouldn't heal. Cardew's new direction was, namely, one of the most decisive steps toward the break-up of the Scratch Orchestra, ${ }^{35}$ and this sequence of events perhaps reminded Barnard of his own experiences as a former member of a similar ensemble. Cage listened to him carefully, asking some questions now and then. He was not impressed by the sectarian differences, and the whole discussion of these issues seemed to bore him: "I think that these little squabbles in the field of music are foolish..." 36

What about Cage's own compositions mentioned by Barnard? In what way could they be seen as being similar to the practice of the groups for improvised music, including his former ensemble? Did Cage take a distance from this because of Barnard's opinion that the performance of his pieces represented a "good model" 37 of the anarchist practice, that the performance required from the players that they listen to each other instead of being dominated by the fixed score, that the pieces were indeed didactic? Did Barnard really listen to these pieces carefully? Or did he just take for granted the words their performance instructions were made of? But these words are actually written down in a particular way. The printed scores of Child of Tree, Branches and Inlets, namely, reproduce

33 Quotation no. 22, taken from Emma Goldman's Anarchism; cf. Cage, "Anarchy," 125 et seq.

34 Cage and Barnard, Conversation without Feldman, 5.

35 According to another protagonist, who recently returned to this wound, the break-up of the ensemble was accelerated through the staging of the new piece, a certain kind of opera, which was intended to present the members' views on the recent events. Cf. John Tilbury, Cornelius Cardew (1936-1981): A Life Unfinished (Matching Tye, Essex: Copula, 2008), 528 et seq

36 Cage and Barnard, Conversation without Feldman, 10.

37 Ibid., 14 . 
Cage's respective manuscripts, which are indeed difficult to read not just because of their particular syntax - unusual in relation to the rules of English grammar - but also because of the way they are written down: the text includes numerous words and phrases which are struck through as well as insertions on both sides of the respective line. Sometimes not just the line, but also the insertion is corrected through another insertion, keeping the traces of all the stages of the working process and forking the line into something like branches. The final version of the instructions is therefore not evident at all, but should be searched for in this verbal forest, between widely branched lines, which make it difficult, if not impossible, for everyone who wants just to pass rapidly through the text. Instead, the verbal instructions require a dedicated reader who will find his own way through the enchanted forest. It is not difficult to find just the start of this way, but even the instructions themselves; when they are finally transcribed from Cage's manuscript, they seem to be rather puzzling, like ambiguous oracles.

According to their verbal instructions, both Branches and Inlets (as well as Child of Tree) indeed presume that the improvisation equals their performance. But this improvisation seems to be rather peculiar, primarily because during the preparation of the pieces for the performance almost all of the significant decisions should be left to I Ching. Thus in Child of Tree chance operations should decide the number of sections within the prescribed total duration of the piece. Also the number of instruments and their setting in each section were left to chance operations. In Branches chance decides even the silences between the single variations, whether they should occur at all and how long they should be. More decisions are left to players in Inlets, where they can choose the total duration of the performance as well as the duration of the improvisation on the single conch shell. But when the player of these pieces begins to improvise, after all the decisions formerly made by chance operations, the instruments will make it difficult for him to take the beaten path. This is because a pod of the poinciana tree, a cactus or conch shells (to say nothing of dry leaves, pine cones, dry grass or similar instruments) do not imply any difference between usual and unusual ways of playing. On the one hand, a player simply cannot know what is actually the right way to play such an instrument, and on the other, such an instrument doesn't offer a large number of possibilities as to how it could be played. Thus, an instrument itself restricts the player's arbitrariness. For the players it is not even necessary to listen to each other, because each of them is always already attentive to the results of the chance operations, on one side, and to the limited possibilities of the instruments, on the other. It is as if the performers are nothing but simple listeners dissolving into the matter being performed.

Not just their verbal instructions, but also the pieces themselves thus resemble the structure of the forest. But what kind of forest? A small grove of seedlings? A regularly structured dark pinewood? A pathless rainforest? But what about the branches of the river? Do the pieces resemble some bifurcated paths? Or do they, rather, resemble the branching of genera and species - at the Porphyrian tree? What about Inlets, a piece in which Pritchett found something "elemental"38? What about Anarchy? Besides the

38 "The three sounds of the piece are related thematically, in their 'elemental' nature - water, fire, air. The piece thus presents a very simple tableau: first the sound of water, then the sound of fire, then the two together with the blown conch shell tone, the sound of air" (Pritchett, The Music of John Cage, 195). 
different lengths of single poems, chance determined also the lengths of their lines. In the cases where the small number of quotations was used as a textual source, the lines of the poem are shorter, with the frequent repetitions of the same words or short phrases. The repeated word thus always appears in the new constellation, as in the case of poem no. 6, which begins with the repeating word "allishness" and the phrase "therefore is simple," each time giving another letter to the vertical string of the poem. ${ }^{39}$ The longer lines of other poems consist of the longer parts of the quotations, and so the temporary sense of the phrases lasts longer, appearing and disappearing like a poorly marked path in a bushy rainforest. At the end of poem no. 13 the unexpected relations between phrases occur, while the borders of the phrases become vague. ${ }^{40}$ This is not the case just in the poems consisting of longer lines: the unexpected relations emerge each time anew, each time differently. The sense appears spontaneously, lasts for a moment, and disappears. In the poems time to time the word "music" occurs, referring to the auditory sphere (other such words are "musicians" and "silence"). ${ }^{41}$ At the end of poem no. 14 music appears unexpectedly in the phrase "To change the nature of music" ${ }^{2}$ detaching it from the previous pulverised verbal material, in order to immerse the very "music" in silence.

Since the quotations are completely reproduced before the cycle, it is possible to discern what they are about, but they gave birth to something quite different. "Anarchy was written to be read out loud," 33 says Cage in the foreword. What happens then? In the conversation with Barnard, Cage gave an indirect answer to this question, speaking on the basis of own experiences as a performer of his own textual pieces. Keeping a distance toward his dialogue partner's tirade against "popular cultural imperialism," ${ }^{4}$ perhaps because Barnard was so self-confident, Cage mentioned some record companies which combine in their catalogues "popular" music on the one hand and "avantgarde" music on the other - that is, in order to bring both kinds of music to the same audience. Among them was a record company which organized a live performance of the third part of Cage's extensive text piece Empty Words in 1977 in Teatro lirico in Milan. Cage spoke of his unusual experience, but in his story a certain distance toward Barnard's views could be felt again. Although the audience was turbulent from the start, and in time an uproar began that transformed the quiet reading with a slide-projection into something like a happening, Cage insisted that the audience in the end was not homogenous, that it didn't act like a single unit. Was this performance successful, despite the fact that the audience interrupted the projection of the slides and the fact that Cage's voice was almost completely covered by the noise the audience made? Cage was not sure whether it was. Was it a success because it provoked the audience into becoming active, as indeed the performance was viewed by the owner of the record company and by Barnard? Or did the activity of the audience just show its inability to

39 Cage, "Anarchy," 158.

40 Ibid., 186

41 The words "music" and "silence" come from quotation no. 25 (taken from Cage's $M$ ), and the word "musicians" from quotation no. 17 (taken from Emma Goldman's book).

42 Cage, "Anarchy," 190.

43 Ibid., 122.

44 Cage and Barnard, Conversation without Feldman, 18. 
listen to what they'd come to hear? In other cases, however, Cage preferred to keep quiet, both as a listener and as a performer, if there was a distinction between the two. Thus in the verbal instructions for the performance of Child of Tree, when it came to improvisation, Cage added the following sentence: "There is no need for a great deal of activity." ${ }^{45}$ Although this sentence was struck through, it was maintained in the published manuscript, as one of the branches.

Noticeable in Cage's answer to Barnard's first question was not just his distance to his own former proposal to make musical activities more social and anarchically so, but also that of treating musical questions as something of secondary importance. "My ideas," wrote Cage at that time, "certainly started in the field of music. And that field, so to speak, is child's play. [...] Our proper work now if we love mankind and the world we live in is revolution.” ${ }^{46}$ But Cage himself, as his dialogue partner noticed, didn't follow his own former call, didn't leave this field - whose importance equaled child's play - in order to dedicate himself to more important tasks. Moreover, it seemed that he dedicated himself thereafter even more to composing music, referring in the conversation to the promise he once gave to Schoenberg, one of his music teachers. Was this dedication to music, after its denigration to the field of secondary importance, just a result of the change in atmosphere, of the "dumbfounding" ${ }^{47}$ events in the years since then, as Cage indicated? Pritchett as well noticed a certain change in Cage's work since that time. Speaking of the "return to composition" 48 in Cage's work since the end of the sixties, he defined it as a move away from the anarchy of the previous works back to the compositional structure, to the way of composition that implied a certain hierarchy, that is, to music notated in the traditional way presuming the division between composer (as someone who tells other people what to do), performer and listener. On another occasion Pritchett spoke of the diversity of Cage's pieces in the same period, finding their inner unity in the "rejection of the idea of stylistic progression." 49

The tone of Cage's discourse on music changed indeed. If we compare two of his lectures with the same title, The Future of Music, the tone of the lecture from 1937 differs from the tone of the lecture from 1974. The first of them, with the subtitle Credo, is not just a statement of belief, which proposes even the substitution of the word "music" for another one, but is also carefully formulated and appears at the begin of the first collection of Cage's writings, as a manifesto, a grounding gesture of the actions to come. In contrast to that, the second lecture, appearing at the end of Cage's collection that consists mostly of poetry, seems to be almost nonchalant, listing all sorts of contemporary compositions, as if the future had already arrived and we had nothing to do but to float in a stream. "The fences have come down and the labels are being removed. An up-to-date aquarium has all the fish swimming together in one huge tank." ${ }^{1}$

45 Cage, Child of Tree ..., 7

46 Cage, A Year from Monday ..., ix.

47 Cage and Barnard, Conversation without Feldman, 7.

48 Pritchett, The Music of John Cage, 162.

49 Ibid., 173.

50 "If this word 'music' is sacred and reserved for eighteenth- and nineteenth-century instruments, we can substitute a more meaningful term: organization of sound." (Cage, Silence, 3 )

51 John Cage, Empty Words: Writings '73-'78 (Middletown: Wesleyan University Press, 1979), 179. The metaphor of aquarium appeared in the foreword to one of Cage's previous books; cf. John Cage, Notations (New York: Something Else Press, 1969), unpaginated. 
Was Cage's return to composition, after his denigration of music and the proposal to leave it for a more important task, a sign of liberation that came about in the meantime? Was the contrast between two gestures noticeable in Cage's conversation with Barnard - that is, his effort to meet his dialogue partner halfway, to agree with Barnard's opinion that music should be changed in order to be able to change the society in the right way, on the one hand, and the distance toward Bernard's views, on the other - reconciled through the advent of the new times, where it was possible for the composer to dedicate himself to music, because the principles of anarchy had finally became a reality? The Cage scholars mentioned above seem to interpret the change of Cage's work in this way. Pritchett thus spoke of the diversity of Cage's pieces in the period after the sixties - of diversity that included pieces with "political themes" 52 as well as the "extravagant spectacles," 53 such as Europeras - as being successors of Cage's former anarchic circuses. On the other side, Haskins found Cage's music to be didactic until his very last works; the Number Pieces were just less loud and more similar to traditional music than Cage's former works.

But this interpretation of the simultaneity of Cage's two gestures seems to be just an echo of Cage's own interpretation, of a certain eschatology of music. After all, in the second of his lectures on the future of music, mentioned above, Cage distinguished some periods in the history of music, with the most important changes occurring with the "Renaissance-honored distinctions between composers, performers, and listeners." ${ }^{54}$ From that point on music was constituted not just through the separation of musical sounds from non-musical ones, but also as an "activity separated from the rest of life," 55 being thus dominated by "schools, conservatories, and music critics." ${ }^{56}$ In contrast to that, the "music's ancient purpose - to sober and quiet the mind," 57 is again contemporary, because "music has already taken steps in this direction," 58 saving itself from academic isolation, from the sterility of music experts and their knowledge. Since the change was already there, Cage's description of the future of music was actually the description of eternity, of the end of history after "the battles won." ${ }^{2}$ In contrast to the former condition, when the single tree of music was controlled by the academy, the change made possible the forking of music into different branches, so that the "practicality of anarchy" 60 in some pieces could exist side by side with pieces like Cage's cycles of études, which are "extremely difficult to play," ${ }^{61}$ requiring thus not just the separation of composer, performer and listener, but the very virtuoso player.

Cage's eschatology of music postulated an existence of two crucial events: music changed essentially for the first time when it was separated from life and thus fell into the sphere of death, and for the second time, when it returned to life and thus expanded

52 Pritchett, The Music of John Cage, 192.

53 Ibid., 197.

54 Cage, Empty Words, 181

55 Ibid., 177.

56 Ibid., 180

57 Ibid., 181

58 Ibid., 181

59 Ibid., 180

60 Ibid., 183.

61 Ibid., 184. 
in all directions. But Cage's description of this expanding, his discussion of the numerous branches of music having developed after the battles won, was rather peculiar. His description of the contemporary situation of music was, namely, limited to recent compositions, as if the anarchic freedom which occurred at the end of music history was embodied in something objectified, in some musical works - and only there. But by claiming anarchy to be something objectified, didn't Cage at the same time presuppose that the composer of the respective works should necessarily be someone who told other people what to do - even if the decisions should be made by I Ching? Didn't Cage presuppose at the same time that the performer of the respective works should necessarily be obedient to their structure - even if this structure should be determined by the chance operations? Finally, didn't Cage presuppose at the same time that the listener of the respective works should necessarily realise just a certain sense of these works, in order to sober and quiet his own mind? Returning once again to the conversation between Cage and Barnard, wasn't this presupposition just another side of Barnard's permanent demand for a certain music that should "affect" 62 the greatest possible number of listeners? If Cage just repeated Barnard's argument in the opposite direction, was there actually any essential change in the period after the battles won?

When Daniel Charles, trying to determine the relation between music and anarchy, recognised in Cage's compositional gesture the "return to origin" (retour à l'origine), ${ }^{63}$ adding that this return could be related to the "classical" aesthetic positions "just indirectly," ${ }^{44}$ he revealed the limits of his own research at the same time. This is because he merely repeated Cage's argument mentioned above, implying that musical anarchy should take the form of certain musical objects, namely, of Cage's own works. Charles took into consideration the structural changes of three instances, of the instances whose emergence, according to Cage's eschatology of music, marked the fall of music into the sphere of death. In Cage's musical anarchy, "the composer is nothing but the simple listener," "the listener himself becomes the performer" and the "performer has a tendency to dissolve into the matter performed." ${ }^{65}$ Although Charles mentioned that Cage's ambition was to "examine the most general condition of all music" (la condition la plus générale de toute musique), ${ }^{66}$ he separated Cage's works from those of all others, as if some essence of music was embodied there, related just indirectly to all other musical works.

But what would happen if we were to take Charles at his word, when he claimed the examination of the most general condition of all music to be Cage's concern? What would happen if we were to take his argument literally? In this case the return to origin would not put into parenthesis just classical aesthetic positions, as Charles did, but every compositional practice, including Cage's own and thus would make perceivable another tone of Charles' argument on musical anarchy. Having this change of tones in mind, musical anarchy would not appear just embodied in some musical works, just

62 Cf. Cage and Barnard, Conversation without Feldman, 8 et seq.

63 Daniel Charles, "Musique et an-archie," in Gloses sur John Cage, by Daniel Charles (Paris: U.G.E., 1978$), 106$.

64 Ibid., 106.

65 Ibid., 100 .

66 Ibid., 93. 
in the most recent ones, just in the works of Cage, in contrast to other ones, but could also be constitutive for all music, for that which is musical as such. Is not the composer as such anything but a simple listener? Has not the performer as such a tendency to dissolve into the matter performed? Does the listener as such just catch the previously determined sense of the piece? Charles seemed to indicate the change of tones using the hyphen, which separated occasionally - from the title of his essay on - the first syllable of the word anarchy from the stem (an-archie), suggesting that every origin, every $\alpha \rho \chi \eta$, should be put into parenthesis, although Charles found at the same time the music of Cage to be privileged through its return to origin. But if the an-archy was marked by the "impartible passivity of the com-passion" (passivité - impartageable de la com-passion $),{ }^{67}$ by passivity more passive than any inaction, it didn't relate to any music in advance (not even to music that presupposed a certain inactivity, for example, the inactivity of the composer who left the determination of certain dimensions of the composition to other instances, such as chance operations), being compassionate to every event as music. The an-archy, as groundlessness itself, could be compassionate to Cage's music as well to Schubert's. Because of it the composer as such was nothing but the simple listener of the musical material, every time anew, every time individually, assisting in its forming into the piece. Because of it the performer as such had a tendency to dissolve into the matter performed, whether playing Cage's music or playing Schubert's. Because of it the listener as such let the music reveal itself in this or that way, each time differently, precisely because it revealed itself individually.

Was Cage himself attentive to this branching of anarchy, marked even by the branching hyphenation, of the word itself? In the conversation with Barnard the double gesture of his responses seemed to give the answer: when he agreed with Barnard's opinions suggesting that music should be changed in order to be able to change the society in the right way, to persuade people, his discussion presupposed anarchy to be a condition grounded on a certain origin, on the "ideology implicit in the pieces." ${ }^{8}$ On the other side, when he kept a distance to Barnard's opinions, he seemed to prefer to listen to the appearance of something as music, its coming and going. Moreover, both of Cage's gestures were noticeable even in the foreword to his collection $A$ Year from Monday, which Barnard cited in the foreword to the printed edition of Conversation without Feldman as an origin that should be returned to. Because the foreword to Cage's collection of writings included not just the call for a certain way of getting musical things done, but also the description of the recent changes. Expressing his proposal to make musical activities more social and anarchically so, Cage added immediately: "As a matter of fact, even in the field of music, this is what is happening." ${ }^{69}$ A catalogue of respective names followed, testifying to the fact that the changes were already underway. Should one therefore insist on something that is already there?

However, the first of Cage's gestures, his acceptance of Barnard's opinions, perhaps simultaneously implied the branching of anarchy. Maybe Cage could move toward music grounded on a certain program - or ideology - because he presupposed that the

67 Ibid., 108

68 Cage and Barnard, Conversation without Feldman, 11.

69 Cage, A Year from Monday ..., x. 
composer as such was not the one who knew what was going on, that the composer as such couldn't control the piece, even in a case when he didn't explicitly leave the decisions to another, for example, to I Ching. Did Schubert know what was going on when he composed his music? Did he know what emerged through the act of composing? Did the greatest music experts actually know that? After all, did not Cage, in the foreword to Anarchy, say that his task was "to find a way of writing which though coming from ideas is not about them"? ${ }^{70}$ And yet, didn't his distance imply also something else, namely, the presupposition that explicit intervention was not necessary because the changes in the right direction were already underway?

But Cage was perhaps more attentive to the branching of anarchy than it seemed. In Conversation without Feldman both of the dialogue partners spoke of different kinds of music, among them of the music committed to the classical aesthetics, as Charles would say. Thus Barnard, speaking of the recent music of Cornelius Cardew, related this music repeatedly to a "19th century pastiche," 71 always in the derogative sense. Cardew, namely, criticises the "modern music ... because it's bourgeois. Then he turns around and holds up people like Schumann and says that their results are much better." ${ }^{2}$ Barnard found the recent music of Cardew to be contradictory: turning back to the formulas which resembled the music of the 19th century and at the same time declaring these formulas to be something elapsed, something bourgeois. But Barnard himself, by mentioning the examples of recent political music not contaminated by this contemptible music of the past, which was of course left behind by every progressive musician like him, presupposed this contemptible music to be something bourgeois. In contrast, Cage in his responses during the conversation never used this identification. When he mentioned some composers from the 19th century - once he spoke of "Chopin and Schubert," on another occasion of "Schubert or Chopin"73 - he seemed to be more benevolent toward them than contemptuous of them. As well, his attitude toward popular music and jazz seemed to be more compassionate than Barnard's, although Barnard repeatedly expressed the opinion that music should affect the greatest possible number of listeners. Didn't Cage's benevolence toward these kinds of music testify that he conjectured some anarchy beyond all music, regardless of its actual kind?

And yet the conversation between Cage and Barnard proceeded without the third one: Morton Feldman. Feldman didn't participate, but he was present nevertheless, being the subject of two of Barnard's questions. In both cases Feldman served as a particular reference point. Barnard thus contrasted his music with the explicitly political pieces by Cardew and Christian Wolff, claiming that their music was "more 'accessible" than Feldman's "to a general sort of audience." ${ }^{74}$ In contrast, the popular music audience "can't relate to it at all," finding his music to be "very alienating." 75 Cage just omitted these remarks on Feldman, turning the conversation instead to Cardew, the

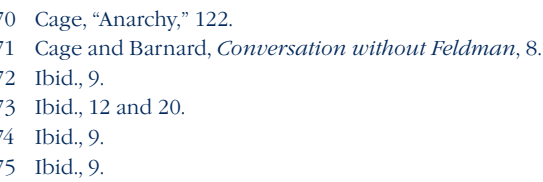


former role model for his dialogue partner, who must have disappointed Barnard so much that he was compelled to return to Cardew so obsessively, commenting on his pieces individually, in contrast to Feldman's music, which was accorded just a few general remarks.

But ten years before Feldman himself had been a dialogue partner in a conversation which likewise proceeded without the third one. Coming back from England, Feldman spoke about his impressions of the English contemporary musical scene. In the efforts of Cornelius Cardew's circle he found "the same talk, the same climate" 76 he remembered from his own experience during the fifties, having been a member of the New York circle. Cardew seemed to be a successor, someone who repeated the gesture of his American colleagues acting according to the motto "Down with the masterpiece; up with art." ${ }^{\prime 7}$

Feldman's opinion served once as a reference point for Barnard ${ }^{78}$ and his music served as a paradigm for the ensemble Barnard participated in. In the conversation mentioned above Feldman pointed out the fact that his music had a tendency to leave the conventional concert setting. "I am looking for something else now," replied Feldman, "something that will no longer fit into the concert hall," 79 into the sanctuary of bourgeois music, as Barnard would say. In the conversation Feldman faced even the question of musical anarchy. When his unnamed dialogue partner ("a friend") mentioned the influential opinion that anarchy in art was unforgiveable, claiming that "one must learn the rules ... if it's only to break them," 80 it seemed that Feldman was on another side. Down with the masterpiece! But Feldman could also call into question what he called a "total consolidation," ${ }^{11}$ a presupposition that the composer (performer or listener, respectively) really knew what he was doing. Did the composer really know what he was doing when he composed? Did he know what actually emerges through the act of composing? Wouldn't anarchy taken as a principle indicate exactly a tendency to such consolidation? But art seemed to include something more, something that exceeded the composer's knowledge:

There's a parable of Kafka about a man living in a country where he doesn't know the rules. Nobody will tell him what they are. He knows neither right nor wrong, but he observes that the rulers do not share his anxiety. From this he deduces that rules are for those who rule. What they do is the rule. That's why all my knowledge doesn't make me understand what Mozart did that I should also do in order to reach a state of artistic grace. ${ }^{82}$

Morton Feldman, "Conversations without Stravinsky," in Give My Regards to Eighth Street: Collected Writings of Morton Feldman, ed. B. H. Friedman (Cambridge: Exact Change, 2000), 50.

77 Feldman, "Conversations without Stravinsky," 50.

78 "Looking back, however, the significance of Ahern during these years (1970-75) should not be underestimated. In fact, what Feldman said of Cardew in 1967 could justifiably have been claimed in relation to Ahern several years later: "If the new ideas in music are felt today as a movement in [Australia], it's because he acts as a moral force, a moral centre." (Barnard, "AZ it was") Cf. Feldman, "Conversations without Stravinsky," 52.

79 Ibid., 57.

80 Ibid., 60

81 Ibid., 56.

82 Ibid., 61. 
During the late seventies, at the moment when the conversation with him took place, Feldman found a way to write music that didn't fit into the conventional concert hall: he started simply to expand the pieces up to extreme lengths, repeating some basic patterns. ${ }^{83}$ The repetitions proceeded irregularly, with this or that minimal variation of the basic pattern, making the course of the piece unpredictable, because the minimal variation of the basic pattern could at every point of the piece be its bifurcation point, as if the piece were a promenade through the forest of forking paths. But Feldman's music faded at the same time as a role model for the musical scene Barnard participated in - not just because of its traditional notation, but also because of its sound, which resembled the sound of chamber music with a piano typical for the music of the 19th century. Incapable of persuading the audience, Feldman's music thus came, in Barnard's opinion, too close to academism, as if it had left anarchy behind, becoming just art, according to the second part (Up with art!) of the motto mentioned above. Becoming bourgeois art, as Barnard would say, falling into the sphere of death. Moreover, Feldman could give him the reason for such an opinion, when he added: "I never fully understood the need for a 'live' audience. My music, because of its extreme quietude, would be happiest with a dead one." ${ }^{84}$ But didn't this distance toward music as a means imply at the same time an attempt to put into parentheses every origin, in order to keep the notion of the musical as such open for every event which could appear as music? Finally, wasn't Feldman, being seemingly backward, as someone whom Barnard and the like-minded progressive musicians left behind, less radical and at the same time more radical than they were?

In the lecture on the future of music Cage honoured Feldman, mentioning him among the individuals thanks to whom the battles had been won. ${ }^{85}$ But also on other occasions Cage pointed out how much the pieces of his old friend, especially the early ones that were marked by the tendency to leave some dimensions of music undetermined, meant to him. But sometimes they were at odds, sometimes they were taking forked paths like those implied in their pieces, even there, where the branching of paths has not been arranged explicitly - in an-archy thanks to which every music leaves us "with an unfathomable mystery." 86 Sometimes their promenades took mysterious ways, finally giving birth to the very mystery of Number Pieces. It was as if Feldman were posthumously speaking through Cage's last pieces, sending last regards to his friend.

\section{Bibliography}

Barnard, Geoffrey. "AZ it was.” New Music Articles 8, no. 7 (1989): 17-20. Accessed 10 February, 2015. http://www.rainerlinz.net/NMA/repr/Barnard.html.

Cage, John. "Anarchy." In John Cage at Seventy-Five, ed. Richard Fleming and William Duckworth, 119-208. Lewisburg \& London \& Toronto: Bucknell University Press \& Associated University Presses, 1989.

83 On this development cf. Sebastian Claren, Neither: Die Musik Morton Feldmans (Hofheim: Wolke, 2000$), 157$.

84 Feldman, "Conversations without Stravinsky," 57.

85 Cf. Cage, Empty Words, 181.

86 Feldman, "Conversations without Stravinsky," 61. 
Cage, John. A Year from Monday: New Lectures and Writings. Middletown: Wesleyan University Press, 1967.

Cage, John. Branches: Percussion Solo, Duet, Trio or Orchestra (of any Number of Players). New York: Henmar Press \& Edition Peters, 1976.

Cage, John. Child of Tree: Percussion Solo. New York: Henmar Press \& Edition Peters, 1975. Cage, John. Empty Words: Writings '73-'78. Middletown: Wesleyan University Press, 1979. Cage, John. Inlets: For three Players, with Conch Player (using Circular Breathing) and the Sound of a Fire. New York: Henmar Press \& Edition Peters, 1977.

Cage, John. Notations. New York: Something Else Press, 1969.

Cage, John. Silence: Lectures and Writings. Middletown: Wesleyan University Press, 1961.

Cage, John, and Geoffrey Barnard. Conversation without Feldman. Darlinghurst: Black Ram Books, 1980.

Charles, Daniel. "Musique et an-archie." In Gloses sur John Cage, by Daniel Charles, 91-109. Paris: U.G.E., 1978.

Claren, Sebastian. Neither: Die Musik Morton Feldmans. Hofheim: Wolke, 2000.

Feldman, Morton. "Conversations without Stravinsky." In Give My Regards to Eighth Street: Collected Writings of Morton Feldman, ed. B. H. Friedman, 50-62. Cambridge: Exact Change, 2000.

Haskins, Rob. Anarchic Societies of Sounds: The Number Pieces of John Cage. Saarbrücken: VDM Verlag Dr. Müller, 2009.

Heidegger, Martin. Der Satz vom Grund. Pfullingen: Neske, 1978.

Pritchett, James. The Music of John Cage. Cambridge: Cambridge University Press, 1993. Retallack, Joan, ed. Musicage: Cage Muses on Words / Art / Music. Hanover \& London: Wesleyan University Press, 1996.

Tilbury, John. Cornelius Cardew (1936-1981): A Life Unfinished. Matching Tye, Essex: Copula, 2008.

POVZETEK

Pogovor brez Feldmana je transkripcija pogovora med Johnom Cageom in Geoffreyjem Barnardom iz leta 1978. Ker je bil razočaran nad svojimi preteklimi izkušnjami - ko je bil član glasbene zasedbe, katere drža je bila "v bistvu anarhistična" -, se je Barnard vrnil h Cageu, saj sem mu je zdel
Cageev poziv po bolj socialnem in anarhističnem glasbenem delovanju, ki ga je izrazil v predgovoru $\mathrm{k}$ svojim zbranim spisom z naslovom $A$ Year from Monday, izvor anarhističnega glasbenega ustvarjanja. Toda Cageeva gesta med pogovorom se izkaže nekoliko dvoumna v pojmovanju njegove ideje same anarhije. 